\title{
CONTRIBUTIONS TO THE BIOLOGY OF THE MACKEREL, SCOMBER SCOMBRUS L. III. AGE AND GROWTH
}

\author{
By G. A. Steven, B.Sc., F.R.S.E. \\ Zoologist at the Plymouth Laboratory
}

(Plate I and Text-figs. I-4)

\section{INTRODUCTION}

The first serious attempt to determine the age and growth rate of the common mackerel (Scomber scombrus L.) appears to have been made by Captain Atwood in 1856 (quoted by Brown Goode, I884, p. I I6) in the Massachusetts Bay area of northern North America. Small fish caught by Atwood in October of that year measuring $6 \frac{1}{2}-7$ in. in length $(16.5-17.5 \mathrm{~cm}$.) he believed to be the young of the year (i.e. they belonged to the O-group). Mackerel belonging to this group he calls 'spikes'. 'Blinks', 'tinkers' and 'second size' fish he assigns to the I-, II- and III-year age groups respectively, but unfortunately gives no data as to the sizes of those categories, merely stating that everyone well acquainted with mackerel makes the same groupings 'as there seems to be a line of demarkation between the different kinds which stands out prominently'. Sixteen years later, on 27 July I872, Malm (I877, p. 409) observed large numbers of small mackerel close inshore in the Gullmarfjord near Christineberg. Several tons of those mackerel were enclosed in a seine, but only ten specimens were retained as all the others escaped through the meshes. These ten fish ranged in length from 67 to $100 \mathrm{~mm}$. and Malm surmised their age to be I3 months. Collett (I880, p. I8) stated that on the coast of Norway I-year-old mackerel are 'fingerlang'. To fish of $20 \mathrm{~cm}$., taken at the end of August, he ascribed (without supporting data) an age of 2 years, with sexual maturity supervening at 3 years at an unspecified length. Marion (I889, p. 86) studied the same species of mackerel in the Mediterranean. In catches obtained at Nice between 2 and 9 May I 888 he found small individuals from 6 to II cm. in length, which he considered to be derived from eggs spawned during the preceding January to March, the range of size being attributed to a spread of spawning activity over those 3 months. In the Gulf of Marseilles, too, at the end of May, Marion obtained mackerel of II cm. which he considered to be the young of the year. At the end of the year fish of I5-I8 cm. were common. Still later, at the beginning of February, both at Marseilles and farther west, Marion noted the presence of mackerel measuring $20-24 \mathrm{~cm}$. 
These he considered to be derived from the previous year's spawningi.e. they were the survivors of the brood that in May, 9 months earlier, were 6-II cm. long.

Along the shores of the Mediterranean mixed fish fry is a readily marketable commodity which commonly includes mackerel. On certain dates in I89I Gourret (I89I, p. 57) recorded the following quantities and sizes landed by a small shore fishery near Marseilles:

$\begin{array}{lrl} & \mathrm{kg} . & \mathrm{cm} . \\ \text { I7-23 April } & 70 & 4-8 \cdot 5 \\ \text { IO-I3 May } & 30 & 2-3 \\ \text { I I, I2, I4, I7 May } & 3 \mathrm{I} & 3-4 \\ \text { 23, 26 May } & 6 & 3-5 \\ \text { 29, 3I May } & 25 & 3-6\end{array}$

The April fry Gourret believed to be derived from the earliest spawning of that year, perhaps in January. The various May fry he ascribed to spawning in February (5-6 cm.); March (4-5 cm.) and even April (2-3 cm.).

In I892 (pp. 232-3) and again in I896 (p. 3I4) Cunningham expressed the belief that mackerel of from 22.2 to $23.5 \mathrm{~cm}$. in length, caught on Io June, must be more or less exactly I year old. Others taken on 23 June having a length range of $29.5-32.8 \mathrm{~cm}$. he regarded as precisely 2 years old. Still others of I6-2I cm., taken in November, were assumed to be 16 months old. This discrepancy Cunningham attributed to individual variation in size, but was greatly perplexed by a single specimen of $\mathrm{I}_{3} .8 \mathrm{~cm}$. taken in September 'which could not have reached that length in 2 or 3 months and must have been an unusually small specimen at I4 months'. Cunningham's age estimations were based on the erroneous belief that in all the mackerel of the region spawning is 'approximately simultaneous', proceeds very rapidly when once begun, and is limited definitely to one short period of the year extending from about the beginning of June to mid-July (Cunningham, I889, p. 25; I896, p. 313: cf. Steven, I949, p. 565).

Matthias Dunn (1893, pp. 4-5) expressed the firm opinion that in the western end of the English Channel young mackerel 5-6 in. long (I2.7I $5.2 \mathrm{~cm}$.) at the end of August, are derived from that year's spring spawning. According to Dunn, these small fish stayed inshore for a further 2 months or so, growing meanwhile at the rate of about $\mathrm{I} \frac{1}{4}$ in. $(3.2 \mathrm{~cm}$.) per month. By about the end of October when $7 \frac{1}{2}-8 \frac{1}{2}$ in. long (I9-2I.6 cm.) they disappeared from Dunn's ken until about the beginning of the following June, by which time they had attained a length of from 9 to II in. $(22 \cdot 9-27 \cdot 9 \mathrm{~cm}$.). Ehrenbaum (1923, p. 2I) records that Knut Dahl caught 3II specimens of small mackerel ranging in length from 6 to $9 \mathrm{~cm}$. in a seine net on I9 July I905. This total was made up as follows:

$$
\begin{array}{lrrrrr}
\text { Length (cm.) } & 6 & 7 & 8 & 9 & \text { (mean 7.8) } \\
\text { No. of fish } & 5 & \text { I02 } & \text { I62 } & 42 &
\end{array}
$$


Ehrenbaum considers all these fish to have been in their first year of life. Young mackerel of similar sizes have also been taken in small numbers, by other observers elsewhere from time to time without their ages having been determined or surmised. These various records are collected by Ehrenbaum (I923, pp. I2-26), who reaches the conclusion that, in general, the growth of the mackerel (Scomber scombrus) during the first year of life 'does not seem to amount to much over Io cm.' (p. 22). Towards the end of their second summer Ehrenbaum considers the average length to be $20-22 \mathrm{~cm}$., and $27-28 \mathrm{~cm}$. in the third summer (p. 39).

Nilsson (I9I4, pp. I-59) was the first investigator to make any real attempt to determine the age and growth rate of mackerel after the first year of life. Age determination in this fish is a matter of great difficulty. No bone has been found which reveals distinctive growth markings either with or without special treatment. Visible and readable markings are present on certain scales, but there is great difficulty in collecting them. They are so small as to be easily rubbed off and transferred from one fish to another in all samples collected by ordinary methods. For scales to be used reliably mackerel must be caught individually, e.g. by hook and line, and each fish kept by itself in a separate container-conditions that cannot easily be met if adequate numbers are to be dealt with. Otoliths are less clearly marked, but with practice readings can be obtained from a high proportion of them in the younger year classes-up to about 6 years. In my experience otoliths from older fish are seldom readable.

Nilsson (I9I4, p. 20) used scale readings checked against a few otolith determinations for age assessment of 208 specimens. From this somewhat scanty material he gives the following lengths reached by mackerel at the end of each year of growth up to and including 6-year-old fish (lengths measured to tip of tail):

$\begin{array}{cll}\text { End of I year } & \text { Maximum recorded length } \quad 22 \cdot 9 \mathrm{~cm} . \\ \Rightarrow & \text { 2 years } & 23 \cdot 5-30 \cdot 6 \mathrm{~cm} . \\ \Rightarrow \quad \text { 3 years } & 3 \mathrm{I} \cdot \mathrm{I}-33 \cdot 9 \mathrm{~cm} . \\ \Rightarrow \quad \text { 4 years } & 34 \cdot 4-36 \cdot \mathrm{I} \mathrm{cm} . \\ \Rightarrow \quad \text { 5 years } & 36 \cdot 7-38 \cdot 5 \mathrm{~cm} . \\ \Rightarrow \quad \text { 6 years } & 39 \cdot \mathrm{I}-40 \cdot 3 \mathrm{~cm} . \\ \Rightarrow \quad 7 \text { years } & 40 \cdot 9-?\end{array}$

Nilsson's findings are in agreement, therefore, with those who ascribe to the mackerel a growth of $20 \mathrm{~cm}$. or more in the first year of life, as against those who consider fish of this size to be at or near the end of their second year of life.

This divergence of opinion as to the growth rate of the mackerel, at any rate in its early years, has persisted. As late as 1939 Le Gall (p. I4) gives the 
following figures based on length frequencies (not given) and the distribution throughout the year of mackerel shoals comprising fish of different sizes.

$\begin{array}{ccc}\text { End of I year } & 8-I \mathrm{I} \mathrm{cm} . \\ \Rightarrow & 2 \text { years } & \text { I8 }-2 \mathrm{I} \mathrm{cm} . \\ " & 3 \text { years } & 26-28 \mathrm{~cm} . \\ " & 4 \text { years } & 30-32 \mathrm{~cm} . \\ \Rightarrow & 5 \text { years } & 35 \mathrm{~cm} .\end{array}$

At the same time, Steven and Corbin (I939, p. I8) made considerably different tentative assessments of age and growth rate based on scale and otolith readings. These were:

\begin{tabular}{|c|c|c|c|}
\hline \multicolumn{2}{|c|}{ End of I year } & & ? \\
\hline "נ & 2 years & Up t & $27 \mathrm{~cm}$ \\
\hline 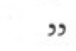 & 3 years & פנ & $3 \mathrm{I} \cdot 5 \mathrm{~cm}$. \\
\hline 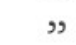 & 4 years & ״ & $33.5 \mathrm{~cm}$. \\
\hline נ, & 5 years & " & $35.0 \mathrm{~cm}$. \\
\hline " & 6 years & 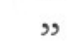 & $35.5 \mathrm{~cm}$. \\
\hline 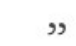 & 7 years & פ & $36.0 \mathrm{~cm}$. \\
\hline
\end{tabular}

According to Sette (I943, p. I54), on the American side of the North Atlantic the fry of the common mackerel reach a length of about $50 \mathrm{~mm}$. in about 70 days after hatching-i.e. by about the end of July for the majority of them. Subsequently, Sette (I950, p. 3I2) states, without supporting data, that these July fingerlings reach a length of 8 in. (i.e. just over $20 \mathrm{~cm}$.) by September; and that they range, in their second year of life, from $25 \mathrm{~cm}$. in early summer to $32 \mathrm{~cm}$. by fall.

Recently, Le Gall (I950) has repeated his I938 figures concerning age and growth of mackerel, again without supporting data, but with the accompanying remark that 'la présence, en quantités parfois très abondantes de la mi-Juin à la fin de Septembre, de jeunes maqueraux de 7 à I I centimètres, confirment l'opinion que nous avons deja émise sur la croissance de ce poisson'.

The two schools of thought on mackerel growth are at variance mainly in their conclusions concerning rate of growth in the first year of life, one school placing the first year's increment at Io $\mathrm{cm}$., or a little over, while the second attributes a length of $20 \mathrm{~cm}$. or more at the end of the first year. Ehrenbaum, of the first school, supports his view by saying that the mackerel is hardly likely to grow faster than cod and haddock, which at the end of their first summer measure only about $14 \mathrm{~cm}$. (I923, p. 23).

Striking confirmation of rapid growth by mackerel in their first year of life has recently been provided by Dannevig (I947, p. 93; I948, p. 219), who has been able to make direct observations on the growth of young mackerel in his fish-hatchery basins at Flødevigen, Norway. On 6 August 1939, a number of young mackerel, $8 \mathrm{~cm}$. in length, appeared in the leads between the basins 
and the lobster hatchery. One was caught and placed in an aquarium where there were large quantities of small Crustacea, and throve remarkably. Later it could be provided with only dead food which did not agree with it, and it died on I September being then I0.5 cm. long. The fish had grown $2.5 \mathrm{~cm}$. in 25 days. Later, on I4 September, about twenty small mackerel were observed in the oyster basins. Their lengths were approximately $15 \mathrm{~cm}$. The basins had been emptied in the spring and those small mackerel must have entered as eggs contained in the water pumped into the basin in May-June of the same year. Dannevig states that young fish could not have passed through the centrifugal pump and lived. $\mathrm{He}$ is therefore in no doubt that those mackerel were young fish of the current year and that they had reached a length of $15 \mathrm{~cm}$. in about 4 months. This agrees closely with Dunn's figures of $12.7-15.2 \mathrm{~cm}$. length at the end of August in the English Channel. There can be now no doubt that mackerel may reach a length of $20 \mathrm{~cm}$. or more in the course of their first year of life.

\section{METHODS}

Investigations by the present author into the life history and biology of mackerel in the English Channel and Celtic Sea have included researches into ages and growth rates. Otoliths have been collected from a total of 8422 fishes, of which $626 \mathrm{I}(74.3 \%)$ have been readable and $2 \mathrm{I} 6 \mathrm{I}(25.7 \%)$, mainly in the higher length groups, have been unreadable. In addition, scales from I 364 fish were collected, but scale reading was discontinued when it was found that a sufficient proportion of otoliths could be read to give reasonably satisfactory results.

The otoliths were collected from each fish by cutting transversely through the head behind the eye at a point immediately in front of the small cavities in which the otoliths lie. There are two otoliths on each side, but the smaller one is useless for age determination. After the cut is made the brain is removed from the remaining posterior part of the cranium. The large otoliths can then be removed, one at a time, by probing for them with a weakly-sprung sharp-pointed forceps. At first this may present some difficulty, but with a little practice the operation becomes both simple and speedy.

As thus obtained, each otolith is covered with soft tissues that must be completely removed before drying. This cannot conveniently be done immediately, as too much time would be taken up in disposing of the sample of fish. The otoliths are therefore stored under water until they can be cleaned. This is best done by making shallow holes in a block of hard, close-grained wood about 9 in. square. One hundred such holes, preferably $\frac{5}{8}$ in. in diameter and $\frac{3}{16}$ in. deep, can conveniently be made in such a block. They should be arranged in regular rows of $\mathrm{IO} \times$ IO. Above the uppermost hole in each vertical row the numerals I-IO are clearly marked. The whole upper surface of the 
block, including the shallow holes, should then be painted black with a waterproof paint that will retain the water with which the holes have to be filled. A specially made block of black plastic material would be even more suitable. On removal from the fish the otoliths are placed in the appropriate hole which is filled with water to keep them wet.

As soon as possible after the sample has been dealt with the otoliths must be divested of all soft tissues adhering to them and placed in numbered containers. Envelopes are unsuitable as the otoliths are so small and brittle that they become lodged in the corners, are hard to see, and often get broken. The best method is to glue small cardboard pillboxes by their bottoms on a square piece of cardboard-100 boxes arranged in rows of Io $\times$ Io to each piece of board.

To clean the otoliths two pieces of cane about $3 \mathrm{~mm}$. in diameter and $\mathrm{I} 5 \mathrm{~cm}$. long are used. Before use each piece is sharply pointed at one end and the points worked gently backwards and forwards on a piece of glass. This breaks up the single fine point and releases the fibres so that a tiny brush of just the right stiffness is formed. With two brushes thus prepared the otoliths can be easily and completely cleaned in water in a solid watch-glass, preferably of black glass, under the low power of a dissecting microscope.

Mackerel scales are very small and easily rubbed off. Special precautions had therefore to be taken to ensure that the scales removed from a fish really belonged to it. Nilsson's method of using hooked fish for scale-reading purposes was therefore adopted. Each fish, on removal from the water carefully suspended from its hook so as not to touch anything, was lowered tail first into a clean, grease-proof paper bag. Both bag and fish were then held firmly in the left hand while the hook was removed. By adopting this method, very few scales actually became dislodged from the fish, and any that were rubbed off were inside that fish's own bag.

For age determination, scales from the anterior part of the body just below and slightly behind the pectoral fin have invariably been used. A scraping in this position is made with a scalpel and the small mass of scales so collected is washed off into a small specimen tube $\left(\mathrm{I} \frac{1}{2} \times \frac{1}{2}\right.$ in.) almost filled with clean water. The tube is then corked. Groups of roo tubes are used, fitted into a IO $\times$ IO arrangement of holes in a block of wood, the holes smaller and deeper than those made for the reception of otoliths.

The scales are collected and stored in tubes because they are too small to be removed individually with a pair of forceps, followed by dipping in water, cleaning between the thumb and first finger of the left hand, and mounting on a microscope slide-as can be done with herring and pilchard scales, for example. In their tubes they can be left for an indefinite period before eventual cleaning and mounting. If left for more than a few days the contents of the tube will smell strongly, but this does no harm; indeed it is an advantage because the scales are more easily cleaned after the organic matter covering 
them has decomposed. In a normal scraping anything up to 500 scales may be present. From amongst these at least three scales should be selected for mounting. In most samples, scales of many shapes and sizes will be found of which only a few will be readable. Most kinds are well illustrated by Nilsson (I9I4, plate I, figs. I-I3). The clearest and most consistent zoning and ringing are found on those shaped as in Nilsson's figs. 8 and II. At least three scales of this type should be looked for amongst the mass of others, and removed to a second watch-glass. There they must be cleaned, in water, under a binocular dissecting microscope, using brushes made from pieces of cane in the way described above. Three such scales are shown in Pl. I, figs. I-3.

\section{AGE AND GROWTH}

In this investigation scales from each of $\mathrm{I}_{3} 64$ fish were mounted on microscope slides previously smeared very lightly with prepared egg albumen. All these scales were separately 'read', and it was found that in 1343 out of the ${ }_{3} 364$ fish $(98.5 \%)$ the readings of all three scales were in agreement. In the remainder, the three scale readings did not all agree. This degree of discordance is not excessive and gives good grounds for assuming that the readings are reliable. Even more confidence can be placed in them when comparison is made with otolith readings from the same fishes. Omitting those fishes that gave discordant scale readings, it is found that in only fifteen out of a total of I343 individuals $(\mathrm{I} \cdot \mathrm{I} \%)$ did the scale readings differ from those of the otoliths. Difficulty in reading the otoliths can very easily account for this discrepancy. These results are shown in detail in Table I.

In consequence of this satisfactory agreement between scale and otolith readings, the collection of scales was discontinued and only otoliths were taken from later samples. In this connexion it must be emphasized that a high proportion of otoliths were rejected as unreadable. Included in this group are all otoliths whose readings were to any appreciable extent doubtful. It is believed to be better to reject completely a doubtful reading than to include it in any group to which it 'probably' belongs.

In the mackerel there are two otoliths on each side-a larger and a smaller one. The latter, flat and somewhat irregularly crescent-shaped in outline, is generally almost completely transparent and never exhibits readable 'ringing' and 'zoning' (Nilsson, I9I4, plate I, fig. I6). The larger otolith is thickest and widest at its posterior end, tapering towards its anterior end where it terminates in two points of unequal length. Nilsson (p. 23) states that this otolith 'can at times have fairly distinct annual rings, especially on the longer of the two points'. In the present investigations reliable readings have been more easily obtained at the blunt posterior end of the otolith. ${ }^{1}$ While it is true that

${ }^{1}$ In Nilsson's own figures (plate I) the markings are clearest at the blunt ends of the otoliths shown. 
markings are often most distinct on the longer point, secondary markings are often so much in evidence that interpretation is difficult or impossible.

Reading is best carried out in a solid watch-glass made of jet-black glass. The otoliths are viewed under water or alcohol by direct illumination. ${ }^{1}$ Thus examined, the central part of the otolith shows up as opaque chalky white. In fish of more than I year the dense central portion is surrounded by a dark, narrow 'ring'. With increasing age further zones and rings are formed (see Pl. I, figs. 4-6).

\begin{tabular}{|c|c|c|c|c|}
\hline $\begin{array}{l}\text { Serial no. } \\
\text { of sample }\end{array}$ & Total fish & $\begin{array}{l}\text { No. of fish } \\
\text { with discordant } \\
\text { scale readings }\end{array}$ & $\begin{array}{l}\text { All scales in } \\
\text { agreement but } \\
\text { differing from } \\
\text { otoliths }\end{array}$ & $\begin{array}{l}\text { Percentage of } \\
\text { fish with all } \\
\text { scales and } \\
\text { otoliths in } \\
\text { agreement }\end{array}$ \\
\hline${ }_{13} A$ & 100 & 6 & I & 93 \\
\hline 15 & $6 \mathrm{I}$ & 4 & I & 92 \\
\hline 24 & 96 & 0 & 0 & 100 \\
\hline 29 & 93 & 0 & 0 & 100 \\
\hline 31 & $7 \mathrm{I}$ & 0 & 5 & 93 \\
\hline 32 & 99 & 0 & 0 & 100 \\
\hline 37 & 13 & 0 & 2 & 85 \\
\hline 39 & 49 & o & 0 & 100 \\
\hline 41 & 100 & Io & I & 89 \\
\hline 44 & 20 & 0 & 0 & 100 \\
\hline 45 & 40 & o & 0 & 100 \\
\hline 46 & 50 & $\circ$ & 0 & 100 \\
\hline 47 & $4 \mathrm{I}$ & o & o & 100 \\
\hline 48 & 39 & 0 & o & 100 \\
\hline 49 & $5 \mathrm{I}$ & 0 & 0 & 100 \\
\hline 50 & 40 & 0 & 0 & 100 \\
\hline $5^{2}$ & 58 & 0 & I & 98 \\
\hline 54 & 45 & 0 & 0 & 100 \\
\hline 55 & 48 & 0 & 2 & 96 \\
\hline $5^{6}$ & 50 & 0 & o & 100 \\
\hline 57 & 100 & o & 2 & 98 \\
\hline $5^{8}$ & 100 & I & o & 99 \\
\hline Total & I364 & $2 \mathrm{I}$ & I5 & $97 \cdot 4$ \\
\hline
\end{tabular}

The central zone is first laid down. This is followed by the first ring which, although formed in winter, does not generally become clearly defined until late spring or early summer when the new season's zone, now forming outside it, serves to show it up. This applies also to all the dark transparent winter rings that are laid down in subsequent years.

Unlike a ring, a zone is recognizable while growing, long before the next ring is laid down demarking its final limit. Thus a 2-zoned fish is one in which a fully developed central zone is surrounded by a fully formed ring, and a second zone, the latter being either partly formed or completed.

New zones, narrow and obviously of recent origin, begin to show up in late spring and early summer. Thus a fish in its second year, caught say in September, will have a distinct second zone clearly noticeable. Its otolith reading will therefore be ' 2 zones $I$ ring', recorded as ' $2-I$ '. The same fish

1 Otoliths that have been stored dry for a long time float in water; alcohol must then be used. 
will continue to have a reading of ' $2-I$ ' until next May or June when a third zone, newly forming, will show up the second winter ring. Readings of ' $I-I$ ', ' $2-2$ ', ' $3-3$ ' have therefore seldom been made; for by the time that the new zone has shown up the immediately preceding winter ring clearly, it has become itself recognizable and must be recorded. It will be convenient, therefore, to discuss otolith readings in terms of zone numbers. An otolith with two zones will obviously have a winter ring between them; a three-zoned otolith will have two intervening rings; and so on.

Since new growth begins about May and continues rapidly throughout the summer and autumn, distinction must be made between fish caught at or near the beginning of the growing season and those caught at or near the end of it. In the early part of the year, before the new seasons's growth has got well under way, a fish whose otoliths record two zones will have completed 2 full years' growth, and really should read ' 2 zones -2 rings'. By the time the second ring becomes definitely recognizable, the third zone will also be showing up and that fish becomes ' $3-2$ '. In late summer and autumn, a fish recording two zones is really aged only I + ; i.e. the second full year's growth is not completed: similarly a three-zoned fish will be $2+$, and so on.

Otoliths from a total of 8422 fish, obtained over the years I936-40 and I948, have been examined. Of these, readings have been possible from 626I fish, and 2I6I $(25.7 \%$ ), mainly from individuals over 6 years of age, have been unreadable.

It has been found convenient to group the 626I fish that gave otolith readings into two groups, ' $\mathrm{A}$ ' and ' $\mathrm{B}$ ', the former having I September and the latter I May as their 'approximate mean date' of capture. Fish included in group A, having the same otolith reading as those of group B, will therefore have a lesser mean length than the latter by the amount of growth that has taken place in the 8 months September to April inclusive.

The mean lengths measured to the nearest centimetre below and suitably corrected, obtained for fishes of different zone readings grouped in this way are given in Table II.

In Text-fig. I the lengths of the May fish are plotted against the numbers of otolith zones which, at that time of year, represent fairly exactly the numbers of completed years of growth. A curve has been fitted empirically to those points. The lengths of the September fish can be plotted on the same graph. On inspection it is found that if, in doing so, the number of years' growth recorded in column 2 of Table II as $\mathrm{I}+, 2+, \ldots$, be taken to read $\mathrm{I} \frac{1}{2}, 2 \frac{1}{2}, \ldots$, then the points (large on the graph) conform remarkably closely to the curve already drawn for the May fish. This means that September fish with $(n)$ zones on their otoliths have completed $\left(n-\frac{1}{2}\right)$ annual increments of growth; that is to say, that half the total growth increment for the year is completed during the 4 months of May-August inclusive, while the other half is spread over the months September-April inclusive. 
Table II. Mean Lengths of Fish of Different Zone Readings (UP TO 6) IN SEPTEMBER AND MAY

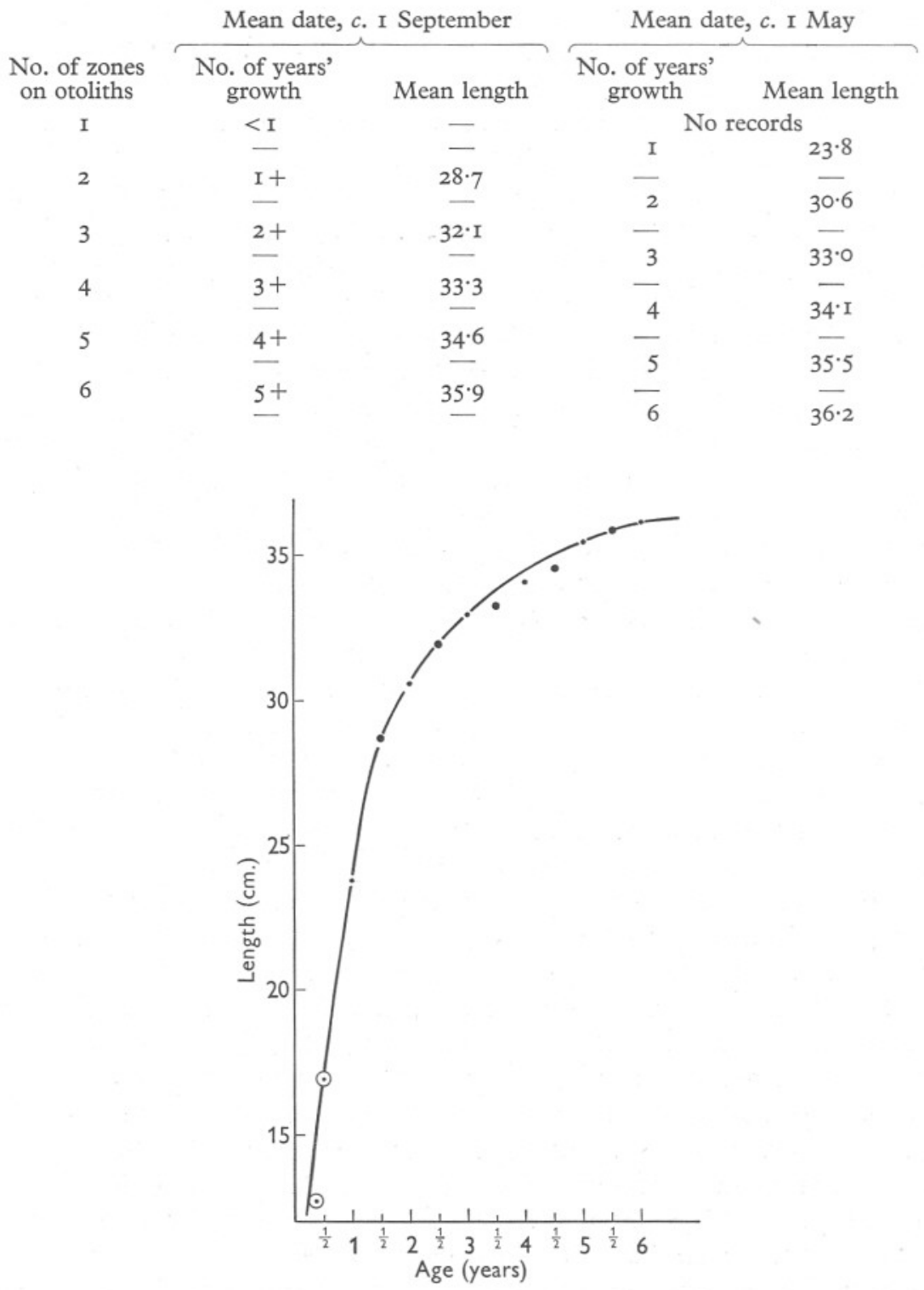

Text-fig. I. Growth of mackerel up to 6 years. 
Small mackerel of less than $15 \mathrm{~cm}$. in length are seldom caught in this area. Occasionally, however, they put in an appearance in shallow water (Steven, 1948, p. 536). Ford (unpublished data) obtained a few small mackerel in Plymouth Sound in August 1926 having a mean length of $15.3 \mathrm{~cm}$.; and again in August 1927 he caught about fifty similar fish in a sprat seine having a mean length of $13.6 \mathrm{~cm}$. (range $12.5-15.2 \mathrm{~cm}$.). In 1937 very large numbers of small mackerel appeared in and around Newlyn harbour, in Cornwall, and in the first days of August the present writer caught 273 of them having a mean length of $12.7 \mathrm{~cm}$. (range $8.0-16.4 \mathrm{~cm}$.). At the end of the same month

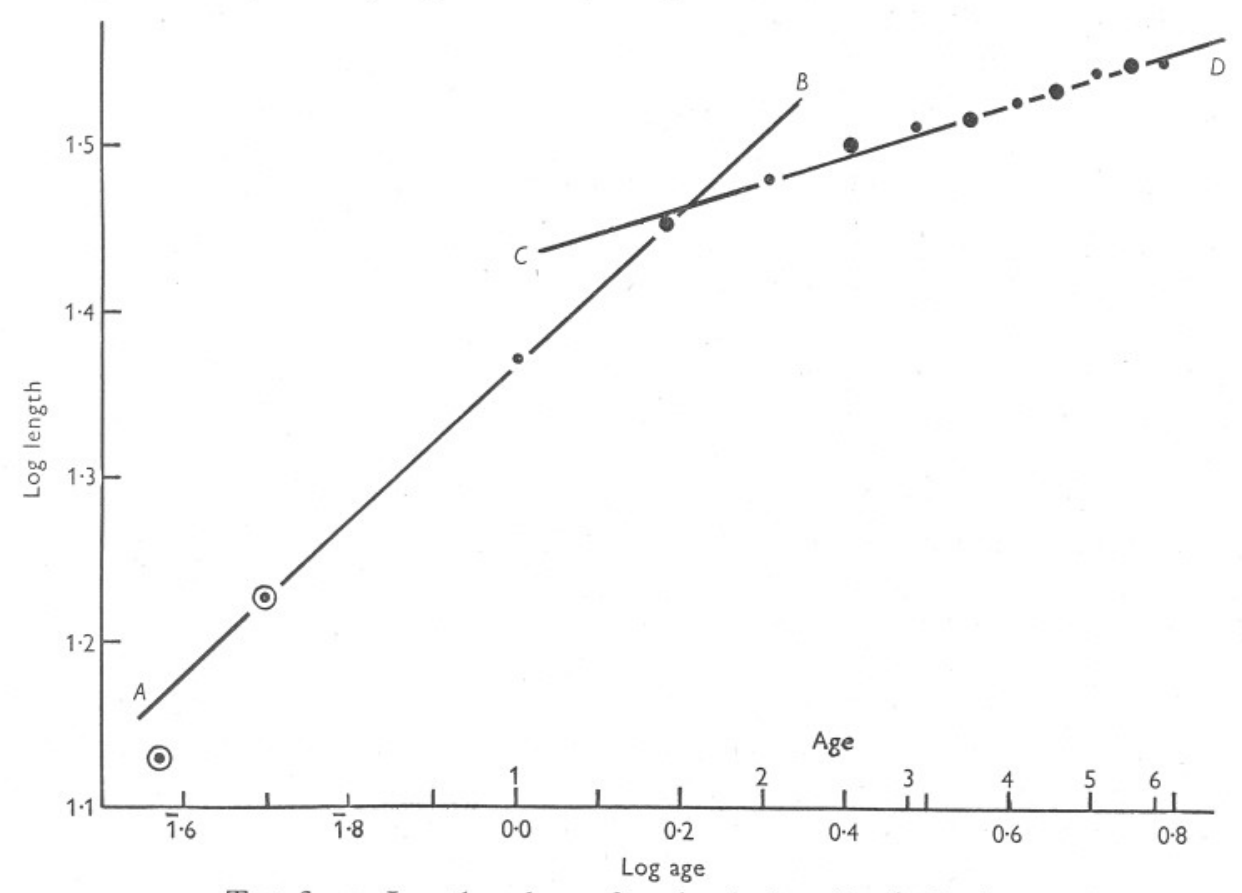

Text-fig. 2. Length and age of mackerel-logarithmic plotting.

84 more small fish were taken having a mean length of $16.9 \mathrm{~cm}$. (range I $4.0-17.9 \mathrm{~cm}$.). Assuming that half a full year's growth takes place, on the average, in May-August inclusive, the fish caught in the first week of August 1937 may be assumed to have made about three-eighths of a full year's growth. The small fish taken at the end of the month would have completed approximately half a year's growth. These points are also plotted (in circles) on the graph in Text-fig. I and appear to conform to the curve derived from plotting the age-length relationships of older fish.

In Text-fig. 2 the same age-length data are plotted on a double logarithmic scale. When this is done it is found that for fish of 2 years and upwards the points fall on or near the straight line $C D$ and that those appertaining to 
younger fish fall on or near another straight line $A B$, with the exception of the early August fish which do not quite conform. On the assumption that they have grown about three-eighths of their full year's increment, the mean length of these fish should have been $14.6 \mathrm{~cm}$. to fall on the line $A B$, a figure that lies well within the length range of the 273 fish from which the mean was derived and may be accepted as being in reasonable agreement for all practical purposes. On the other hand, an adjustment of 3 weeks in their assumed age is all that is necessary to obtain agreement.

There can be little doubt therefore that in the young fish up to about 2 years of age the growth gradient conformed to that indicated by the line $A B$, which provides the expression

$$
L \propto A^{0 \cdot 49} \text {, i.e. } A \propto L^{2 \cdot 06},
$$

where

$$
L=\text { length in cm., and } A=\text { age in years. }
$$

In older fish the growth gradient conformed to that indicated by the line $C D$, which provides the expression

$$
L \propto A^{0 \cdot 15} \text {, i.e. } A \propto L^{6 \cdot 65} .
$$

The two lines $A B$ and $C D$ intersect at a point representing the logarithms of length $29 \cdot 3 \mathrm{~cm}$. (limits $28 \cdot 6-29 \cdot 5$ ) and age $\mathrm{I} \cdot 6$ years.

It seems likely that this point of discontinuity in the growth gradient represents the approximate length and age at which the onset of active sexual development takes place in the majority of individuals, i.e. that the onset of sexual maturity takes place at a length of about $29 \mathrm{~cm}$. in the second year of life. This means that fish hatched in the spring of any year will begin to 'fill up' in the late autumn of the following year and will spawn for the first time during the subsequent spawning season when approximately 2 full years of age. This is in agreement with Nilsson's statement (I9I4, p. 4I) that 'maturity is reached at the age of 2 years' if by this is meant that the fish arrive at first spawning when they are approximately 2 full years old. Confirmation of these results has been obtained from simultaneous observations on gonad development. Le Gall (1950, p. 7I) also states that the onset of first maturity takes place at or over a length of $26-28 \mathrm{~cm}$., but ascribes an age of 3 years to such fish.

\section{Onset of Sexual Maturity}

Data bearing on the onset of sexual maturity in the mackerel of this region have been obtained by examination of 9334 fish in which sex and gonad condition have been determined. The determinations were made by naked-eye observation. Young individuals in which the sex could not be decided by this means have been recorded as immature fish. The later stages of development 
of the sexual organs have been classified according to a scheme similar to that used internationally for the herring and other clupeoids (see Jensen, I950, p. 6), but suitably modified for the somewhat special characteristics exhibited by the mackerel.

Stage O. Immature juveniles. Sex not ascertainable by naked-eye examination.

Stage I. Virgin individuals. Sexual organs very small but sex ascertainable by naked eye. Ovaries rich wine colour and very slender torpedo shape; individual eggs indistinguishable. Testes much paler in colour than the ovaries; also thinner and more blade-like.

Stage II. Maturing virgins (maiden fish) and recovering spents. In virgin fish the ovaries are slightly larger now than in stage I and individual eggs begin to be distinguishable. Testes also enlarging; paler in colour than ovaries. In recovering spents, at this stage, both ovaries and testes are also quite small but flabbier than in virgin fish and generally somewhat bloodshot.

Stage III. Sexual organs considerably larger and occupying about half of the ventral cavity. Differences between virgin fish and recovering spents now scarcely distinguishable.

Stage IV. Sexual organs still growing. Ovaries becoming a pronounced orangeyellow colour with conspicuous opaque eggs. Testes becoming a clear creamy or milky colour.

Stage V. Sexual organs now filling ventral cavity. In the ovary superficial bloodvessels have become large and conspicuous. No transparent eggs. Testes assuming a fairly uniform milky whiteness.

Stage VI. Testes-large, firm and clean milky white. Small amount of ripe milt can be expelled from them on slight pressure.

Ovaries. In the female stage VI has been subdivided into two stages:

Stage (क) VI A. Ripe translucent eggs scattered throughout unripe eggs giving rise to a 'plum pudding' appearance (see Steven, I949, p. 565 and plate I). No ripe eggs free in the lumen.

Stage (P) VI B. Ripe eggs present in the lumen of the ovary which generally must be opened to find them. Externally, the ovary may appear to be in stage V or VI A, but the presence of ripe eggs free in the lumen indicates that one or more batches of eggs have already been spawned. After several batches have been shed the ovary becomes progressively more flabby and bloodshot, especially posteriorly.

Stage VII. Spent fish. Ovaries slack with only residual eggs. Very bloodshot. Testes also small, flabby and bloodshot.

A stage VIII as used for herring (Jensen, I950, p. 6) has not been separately distinguished.

The 9334 fish examined for sex comprised 995 immature juveniles whose sex was not evident from naked-eye observation. The remainder comprised 403I males and 4308 females. Of these 803 males and 68I females were in maturity stage $\mathrm{I}-$ i.e. were virgin fish in which signs of rapid gonad development towards ripening are still absent though the sex is determinable by naked-eye observation. Some females whose lengths ranged from 22 to $28 \mathrm{~cm}$. had ovaries of quite small size that nevertheless exhibited a typically shotten appearance, but which, after the most careful examination, always failed to reveal any residual ripe eggs in the lumen. The explanation appears 
to be that, in those fish, the gonads had progressed a considerable way towards ripeness and then assumed a spent appearance without any ripe eggs having been actually produced and shed. Similar precocity was detectable also in some males over a length range of $24-28 \mathrm{~cm}$. Since these fish-designated 'false stage VII'-had not spawned, they have been grouped with stages $\mathrm{O}$ and I as maiden fish which had not yet reached first maturity.

In Table III the total numbers of fish at the various stages of gonad development have been entered against the length in $\mathrm{cm}$. From this table it will be seen that all fish under $18 \mathrm{~cm}$. in total length were in those stages of immaturity in which the sex was not determinable by naked-eye examination. Fishes in this stage were not uncommon up to a length of $22 \mathrm{~cm}$. after which their numbers diminished and they were almost totally absent in all sizes exceeding $29 \mathrm{~cm}$. Fishes in stage I begin to appear in small numbers at lengths of from I8 to $20 \mathrm{~cm}$. and remain common up to lengths of just over $30 \mathrm{~cm}$. Fishes at stage II, which includes maiden fish with gonads in the very early stages of active ripening, and recovering spents in which the gonads have gone far towards resuming their original appearance in maiden fish, begin to appear at $21 \mathrm{~cm}$. and become plentiful at lengths of $27 \mathrm{~cm}$. and upwards. The later stages, up to and including stage VI, do not appear in any numbers until lengths of $30 \mathrm{~cm}$. and upwards are reached. The table further reveals that spent fish may be at times noticeable in the catches at smaller sizes than fully ripe fish. There are probably two explanations for such apparently anomalous occurrences: (i) that fish in a state of precocious maturity and giving a false appearance of 'spentness' have been mistaken for true spents; and (ii) that, by some vagaries of the fisheries or of sampling, spent fish on occasion were obtained for examination from schools of smallish fish from which no samples were collected when they were in the spawning state.

In further reference to Table III it will be seen that the immature fish of stages $\mathrm{O}$ and I and precocious stage VII are chiefly confined to fish of less than $29 \mathrm{~cm}$. in total length-i.e. they are grouped on the left of the line $A B$ drawn through the table-and that stages III-VII are comprised mainly of fish of $30 \mathrm{~cm}$. and upwards, i.e. they are grouped on the right of the line $A B$. Stage II may be regarded as a transition phase in which the ripening process is actively beginning but has not yet reached the state of very rapid gonad development associated with stage III onwards.

This grouping of the fish in Table III on either side of a line falling between lengths of $29 \mathrm{~cm}$. and $30 \mathrm{~cm}$. agrees well with the figure of $29.3 \mathrm{~cm}$. as the point of discontinuity in the curve of growth derived from plotting log length against log age. There can be little doubt, therefore, that the change in the growth gradient in respect of the age-length relationship is very closely associated with the onset of first sexual maturity. This is further borne out by the fact that if the percentage of fish exhibiting gonad stages II-VII inclusive (Table III) is plotted against length, the derived sigmoid curve 
Table III. Length Distribution of the Various Reproductive Stages

Length of fish (in $\mathrm{cm}$.)

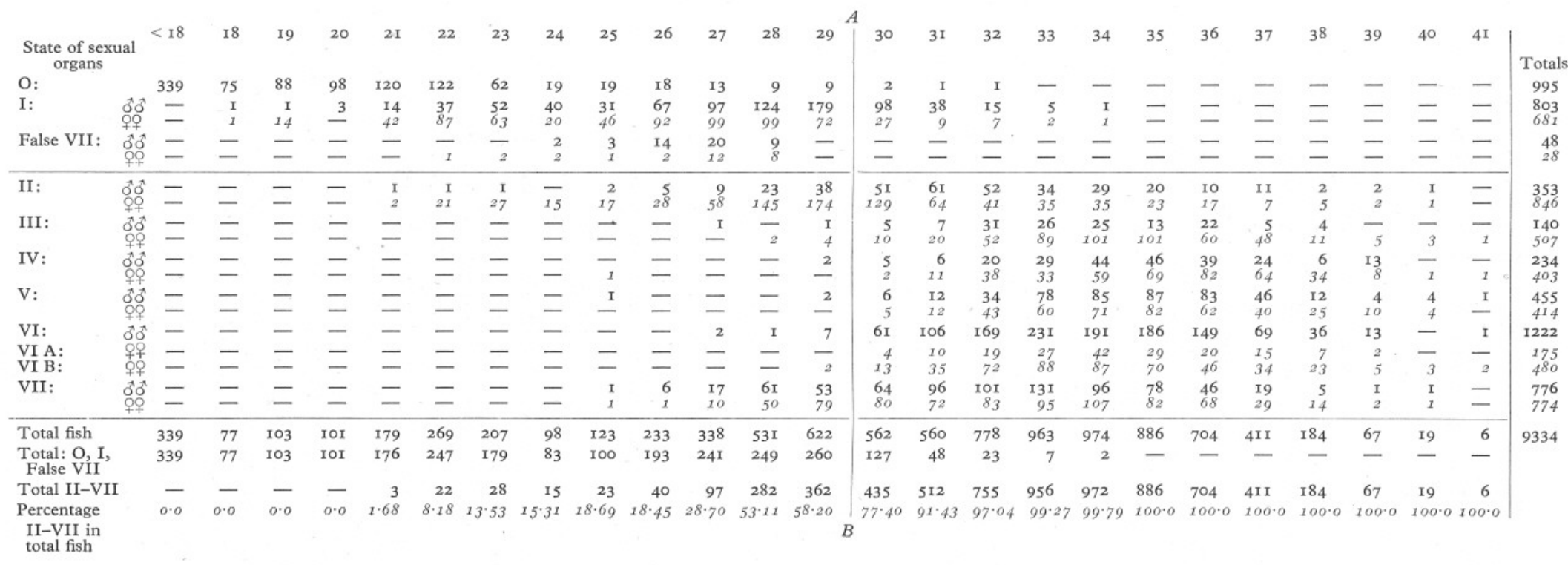


has its point of inflexion at a length of $28 \cdot 8 \mathrm{~cm}$. (limits $28 \cdot 4-29 \cdot 2$ ) (Textfig. 3).

\section{WEIGHT-LENGTH RELATIONSHIP}

Weights to the nearest gram of a number of fish covering the whole range of available lengths have been determined. For this purpose fish under $20 \mathrm{~cm}$. in length are arranged in $\frac{1}{2} \mathrm{~cm}$. size-groups, measured to the nearest $\frac{1}{2} \mathrm{~cm}$. below. Fish over $20 \mathrm{~cm}$. are placed in I cm. size-groups, measured to the nearest $\mathrm{cm}$. below. A correction of half a group unit has been added to all mean lengths. The weight-length data so obtained are shown in Table IV. When plotted logarithmically (Text-fig. 4) a definite discontinuity is manifest in the weight-length relationship at $27.9 \mathrm{~cm}$. mean length (with rather wide limits of c. 25.7-31.6) and $\mathrm{I} 35 \mathrm{~g}$. mean weight.

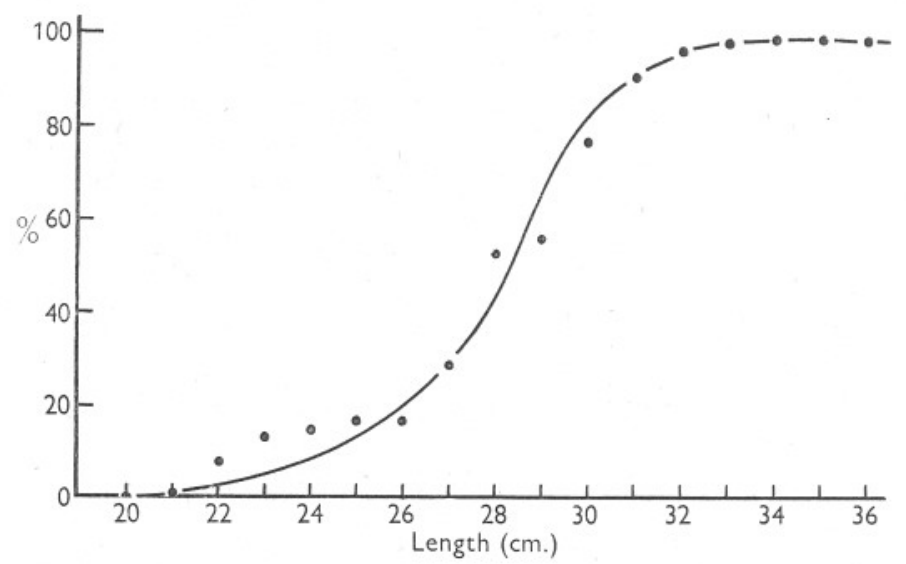

Text-fig. 3. Percentage of all fish examined showing gonad stages II-VII inclusive: in centimetre length-groups.

From $28 \mathrm{~cm}$. down to Io $\mathrm{cm}$. (the smallest fish weighed) the weight-length relationship is expressed by $W \propto L^{2 \cdot 86}$. From $28 \mathrm{~cm}$. upwards the weight increases much more rapidly in relation to length and conforms to the expression $W \propto L^{3 \cdot 54}$. This applies only to fish in the early part of the year when they have recovered from the spent condition and are again actively ripening; comparative figures for newly spent fish have not been obtained.

A change in the weight-length relationship of growing fish appears to manifest itself at a slightly earlier stage than the change in the length-age relationship, but the difference is doubtfully significant, and anyhow the two critical mean lengths are sufficiently close to suggest that both changes may be initiated simultaneously at the onset of first sexual maturity.

Age determination by direct methods has not been possible beyond 6 years. Further researches and improved techniques may increase the range of direct readings-from otoliths, scales or other body structures-by a few years; 


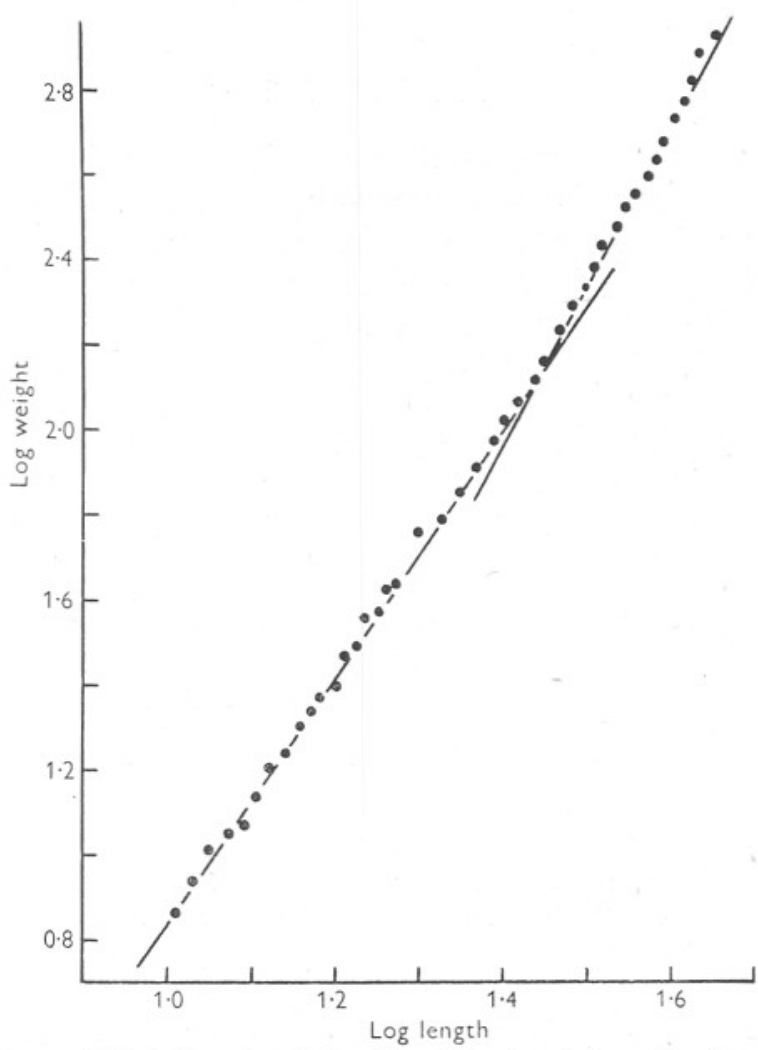

Text-fig. 4. Weight-length relationship of mackerel: logarithmic plotting.

TABLE IV. Weight-LENGTH Relationship

\begin{tabular}{|c|c|c|c|c|c|c|c|}
\hline $\begin{array}{c}\text { Length } \\
\text { group } \\
(\mathrm{cm} .)\end{array}$ & $\begin{array}{l}\text { No. of } \\
\text { fish }\end{array}$ & $\begin{array}{l}\text { Mean } \\
\text { weight } \\
\text { (g.) }\end{array}$ & & $\begin{array}{l}\text { Length } \\
\text { group } \\
\text { (cm.)' }\end{array}$ & $\begin{array}{l}\text { No. of } \\
\text { fish }\end{array}$ & $\begin{array}{l}\text { Mean } \\
\text { weight } \\
\text { (g.) }\end{array}$ & $\sigma$ \\
\hline 10.25 & 7 & 7 & & $2 I \cdot 5$ & II & 62 & 4.7 \\
\hline I0.75 & IO & 9 & & $22 \cdot 5$ & I7 & 72 & 6.8 \\
\hline I I 25 & 22 & 10 & & 23.5 & 25 & $8 \mathrm{I}$ & $7 \cdot 8$ \\
\hline $\mathrm{II} \cdot 75$ & $2 \mathrm{I}$ & II & & $24 \cdot 5$ & 33 & 95 & $8 \cdot 0$ \\
\hline 12.25 & 32 & I2 & & $25 \cdot 5$ & 26 & I05 & 12.9 \\
\hline I $2 \cdot 75$ & 32 & I4 & & $26 \cdot 5$ & I8 & II 5 & 8.6 \\
\hline I3.25 & $3^{8}$ & 16 & & $27 \cdot 5$ & 26 & 129 & $9 \cdot 3$ \\
\hline I3.75 & 25 & I7 & & $28 \cdot 5$ & 39 & I46 & 17.0 \\
\hline 14.25 & 26 & 20 & & $29 \cdot 5$ & 49 & 169 & $12 \cdot 0$ \\
\hline 14.75 & 32 & 22 & & 30.5 & 49 & I94 & I $4: 3$ \\
\hline 15.25 & 20 & 24 & & $3 \mathrm{I} \cdot 5$ & 54 & 217 & 16.2 \\
\hline 15.75 & Io & 25 & & 32.5 & 60 & $24 \mathrm{I}$ & $17 \cdot 7$ \\
\hline $16 \cdot 25$ & I4 & 30 & & 33.5 & 72 & $27 \mathrm{I}$ & 23.6 \\
\hline I6.75 & 12 & $3 \mathrm{I}$ & & 34.5 & 96 & 300 & 25.0 \\
\hline $17 \cdot 25$ & 2 & 37 & & 35.5 & 77 & $33 \mathrm{I}$ & $3 \mathrm{I} \cdot 7$ \\
\hline I $7 \cdot 75$ & 5 & 37 & & $36 \cdot 5$ & 100 & 354 & $35^{\circ} 9$ \\
\hline I $8 \cdot 25$ & I & 42 & & $37 \cdot 5$ & 88 & 392 & $44 \cdot 5$ \\
\hline I 8.75 & 3 & 43 & & 38.5 & 67 & 430 & $47 \cdot 0$ \\
\hline I9.25 & - & - & & 39.5 & 43 & $48 \mathrm{I}$ & 34.4 \\
\hline 19.75 & - & - & & 40.5 & 24 & 542 & 55.8 \\
\hline \multirow[t]{4}{*}{20.5} & 6 & $5^{8}$ & ' & $4 I \cdot 5$ & 8 & 584 & $29 \cdot I$ \\
\hline & & & & $42 \cdot 5$ & 6 & 669 & $24 \cdot 3$ \\
\hline & & & & $43 \cdot 4^{\star}$ & 3 & 782 & - \\
\hline & & & & $46 \cdot \mathrm{It}$ & I & $85 \mathrm{I}$ & - \\
\hline
\end{tabular}

Specimens up to $20 \mathrm{~cm}$. in length were weighed all together in their length groups and the mean obtained by a single calculation: $\sigma$ was therefore not obtained.

* Actual mean (without correction) of fish measured to nearest mm.

$\dagger$ Actual measurement to nearest mm. 
but such determinations are unlikely in the foreseeable future to cover the entire life span. It is worth while, therefore, to use the data already available to calculate approximate theoretical mean lengths and mean weights attained by fish in each year of life until a length of $43 \mathrm{~cm}$. is reached-this being the maximum length recorded in this investigation, except for a single fish of $46 \cdot \mathrm{I} \mathrm{cm}$. total length weighing $85 \mathrm{I} \mathrm{g}$.

Table V. Length and Weight of Mackerel at Different Ages up to 20 Years: uP to 6 Years from Direct ObSERVATION, THENCE BY Calculation

\begin{tabular}{|c|c|c|c|c|c|c|c|c|c|c|}
\hline Age (years) $\quad \ldots$ & I & 2 & 3 & 4 & 5 & 6 & 7 & 8 & 9 & IO \\
\hline $\begin{array}{l}\text { Approximate mean length } \\
\text { (cm.) }\end{array}$ & $23 \cdot 8$ & $30 \cdot 6$ & $33 \cdot 0$ & $34 \cdot I$ & $35 \cdot 5$ & $36 \cdot 2$ & $37 \cdot I$ & $37 \cdot 8$ & $38 \cdot 5$ & $39 \cdot 1$ \\
\hline $\begin{array}{l}\text { Approximate mean weight } \\
\text { (g.) }\end{array}$ & 80 & I 88 & 247 & 278 & 322 & 345 & $38 \mathrm{I}$ & $4 \mathrm{IO}$ & 436 & 462 \\
\hline Age (years) & II & I2 & I3 & I4 & I5 & I6 & I7 & I8 & 19 & \\
\hline $\begin{array}{l}\text { pproximate mean length } \\
\text { (cm.) }\end{array}$ & $39 \cdot 7$ & $40 \cdot 2$ & $40 \cdot 7$ & $4 I \cdot I$ & $4 \mathrm{I} \cdot 5$ & $4 \mathrm{I} \cdot 9$ & $42 \cdot 3$ & $42 \cdot 7$ & $43 \cdot 0$ & \\
\hline mate mean weight & 486 & 509 & 532 & 553 & 574 & 594 & $6 \mathrm{I} 4$ & 633 & $65 \mathrm{I}$ & \\
\hline
\end{tabular}

(g.)

Accôrding to these calculations the single $46 \cdot \mathrm{I} \mathrm{cm}$. fish obtained during these investigations would be 30 years old and should weigh approximately $832 \mathrm{~g}$.

\section{ACKNOWLEDGEMENTS}

The investigations described here and in Parts I and II benefited very greatly from abundant help and advice freely given by many persons. Chief amongst them was Skipper B. Moore of the Lowestoft steam drifter 'B.T.B.' (L.T. II53), who took a keen interest in the work from its inception and on two occasions put his ship at my disposal for special cruises. Other drifter skippers who helped in various ways were E. W. J. Capps (L.T. 89, Present Friends), J. R. Capps (L.T. 240, Fustified), W. A. Capps (L.T. I45, Silver Prince), F. Darkins (L.T. 244, Fustifier), H. Darkins (L.T. 730, Implacable), R. Green (Y.H. 497, Young Fohn), A. W. Jackson (L.T. I72, True Reward), W. G. Jenner (L.T. 89, Present Friends), W. C. Julings (L.T. 277, Oak Apple), T. Lane (Y.H. 105, Wydale), H. Muttett (L.T. 730, Implacable), S. Spilling (Y.H. 7II, Harry and Leonard), W. Thompson, senr. (L.T. 756, Buckler), W. Thompson, jun. (L.T. I217, Golden Chance), L. Tooke (L.T. 256, Welcome Home), A. R. J. Warner (Y.H. 47I, Ocean Swell), A. W. Wilkinson (Y.H. I4I, Playmates), E. J. H. Tallop (L.T. 7I I, Lord Fisher) and Skipper W. H. E. Nicholls of the steam trawler Elk (M. 36).

On the fish-market at Newlyn, Cornwall, where most of the field work was done, $\mathrm{Mr} \mathrm{T}$. Cotton, Clerk to the Harbour Commissioners and the late Captain D. Oliver, Harbourmaster, gave invaluable assistance. It is a pleasure to record my indebtedness also to all the fish-merchants and their employees at Newlyn and to the manager and staff of the Newlyn branch of the Great Grimsby Coal, Salt and Tanning Co. Ltd., for much help and advice. To the 
Newlyn Harbour Commissioners, both individually and collectively, I am grateful for numerous facilities willingly granted. My best thanks are also due to Mr G. M. Spooner for statistical guidance and to Dr H. G. Vevers for translations from Norwegian publications. Mr P. G. Corbin helped with some of the field work, and Mr A. D. Mattacola provided the photographs for Pl. I.

\section{SUMMARY}

Owing to the difficulty of age-determination in mackerel, the age and growth rate of these fish had not previously been satisfactorily determined.

Two schools of thought arose, one attributing a length of little over $10 \mathrm{~cm}$. at the end of the first year of life, while the other ascribed lengths of up to about $25 \mathrm{~cm}$. to I-year-old fish.

The present investigation supports the second school. Direct age-readings from scales and otoliths have been made of fish up to 6 years of age, and the probable sizes at greater ages have been calculated.

There appears to be a critical change in growth characteristics at a mean length of about $29 \mathrm{~cm}$., coinciding with the first ripening of the genital products.

\section{REFERENCES}

Brown Goode, G., I884. Materials for a history of the mackerel fishery. I. Natural history. U.S. Comm. Fish and Fisheries, Commissioner's Report for I881, pp. 9II38.

Collett, R., I880. Meddelelser om Norges Fiske i Aarene 1875-78. Forh. Vidensk.Selsk., Christiania, Aar 1879, No. I, I07 pp.

Cunningham, J. T., I889. Studies of the reproduction and development of teleostean fishes occurring in the neighbourhood of Plymouth. Fourn. Mar. Biol. Assoc., Vol. I, pp. Io-54.

- 1892. On the rate of growth of some sea fishes, and the age and size at which they begin to breed. Fourn. Mar. Biol. Assoc., Vol. 2, pp. 222-64.

- I896. The Natural History of the Marketable Marine Fishes of the British Islands. 375 pp. London.

Dunn, Matthias, I893. The mackerel. Rep. Roy. Cornwall Polytechnic Soc., I893, pp. I-I5.

DanNEvig, Alf., I947. Hvor hurtig vokser makrellyngelen? Naturen, Årgang 7I, Nr. 3, Mars 1947, pp. 92-4.

- I948. Spawning and growth of young mackerel on the Norwegian Skagerak coast. Fourn. Cons. Int. Explor. Mer, Vol. I5, pp. 218-20.

Ehrenbaum, E., I923. The mackerel. Spawning-larval and post-larval forms-age groups-food-enemies. Cons. Int. Explor. Mer, Rapp. Proc.-Verb., Vol. 30, $39 \mathrm{pp}$.

Gourret, M. Paul, I89i. La pêche des mugelières, à Marseille, en r89i. Ann. Mus. Hist. Nat. Marseille, Trav. Zool. Appliquée, T. 4, S. I, année 3, pp. 54-67.

LE GaLL, J., I939. Quelques résultats des recherches faites sur la biologie du maquereau de l'Atlantique. Cons. Int. Explor. Mer, Rapp. Proc.-Verb., Vol. II I (Rapp. Atlantique I937-38), pp. I3-I4.

— I950. Maquereau (Scomber scombrus Linné). Observations faites en 1949 sur sa biologie. Cons. Int. Explor. Mer, Ann. Biol., Vol. 6, pp. 70-I. 
Jensen, Aage J. C., I950. Changes in the quality of the herring in the course of the year and from year to year. Rept. Danish Biol. Stn, No. 5I, pp. 3-17.

Malm, A. W., I877. Göteborg och Bohusläns fauna, Ryggradsdjuren. Göteborg.

MARION, M. A.-F., I889. Remarques relatives au maquereau des côtes Mediterranéennes. Ann. Mus. Hist. Nat. Marseille, Trav. Zool. Appliquée, T. 3, S. I, année I, pp. $83-7$.

Nilsson, D., I914. A contribution to the biology of the mackerel. Cons. Int. Explor. Mer, Publ. Circon., No. 69, 59 pp.

Sette, Oscar Elton, 1943. Biology of the Atlantic mackerel (Scomber scombrus) of North America. I. Early life history, including the growth, drift, and mortality of the egg and larval populations. Bull. Fish \& Wildlife Service, U.S. Dept. Interior, Vol. 50, pp. I49-237 (Fishery Bulletin No. 38).

— I950. Biology of the Atlantic mackerel (Scomber scombrus) of North America. II. Migrations and habits. Bull. Fish. E Wildife Service, U.S. Dept. Interior, Vol. 5I, pp. 249-358 (Fishery Bulletin No. 49).

Steven, G. A., I948. Contributions to the biology of the mackerel, Scomber scombrus L. Mackerel migrations in the English Channel and Celtic Sea. Fourn. Mar. Biol. Assoc., Vol. 27, pp. 517-39.

- I949. Contributions to the biology of the mackerel, Scomber scombrus L. II. A study of the fishery in the south-west of England, with special reference to spawning, feeding and 'fishermen's signs'. Fourn. Mar. Biol. Assoc., Vol. 28, pp. 555-81.

Steven, G. A. \& Corbin, P. G., I939. Mackerel investigation at Plymouth. Preliminary report. Cons. Int. Explor. Mer, Rapp. Proc-Verb., Vol. II I (Rapp. Atlantique 1937-38), pp. I5-18.

\section{EXPLANATION OF PLATE I}

Fig. I. Mackerel scale showing one ring and two zones: $\times 55$. From a fish $28 \mathrm{~cm}$. in length, 9 October 1936.

Fig. 2. Mackerel scale showing two rings and three zones: $\times 44.3$. From a fish $33 \mathrm{~cm}$. in length, 8 June 1937.

Fig. 3. Mackerel scale showing three rings and four zones: $\times 48.5$. From a fish $34 \mathrm{~cm}$. in length, 24 September 1936 .

Fig. 4. Otolith showing one ring and two zones: $\times 12 \cdot 8$. From a fish $29 \mathrm{~cm}$. in length, 22 September 1936.

Fig. 5. Otolith showing two rings and three zones: $\times 12 \cdot 4$. From a fish $33 \mathrm{~cm}$. in length, 23 July 1936.

Fig. 6. Otolith showing three rings and four zones: $\times 12.05$. From a fish $34 \mathrm{~cm}$. in length, 22 September 1936.

The illustrations in this plate are all from un-retouched photographs. 
Journ. MAR. Biol. Assoc. XXX (3)
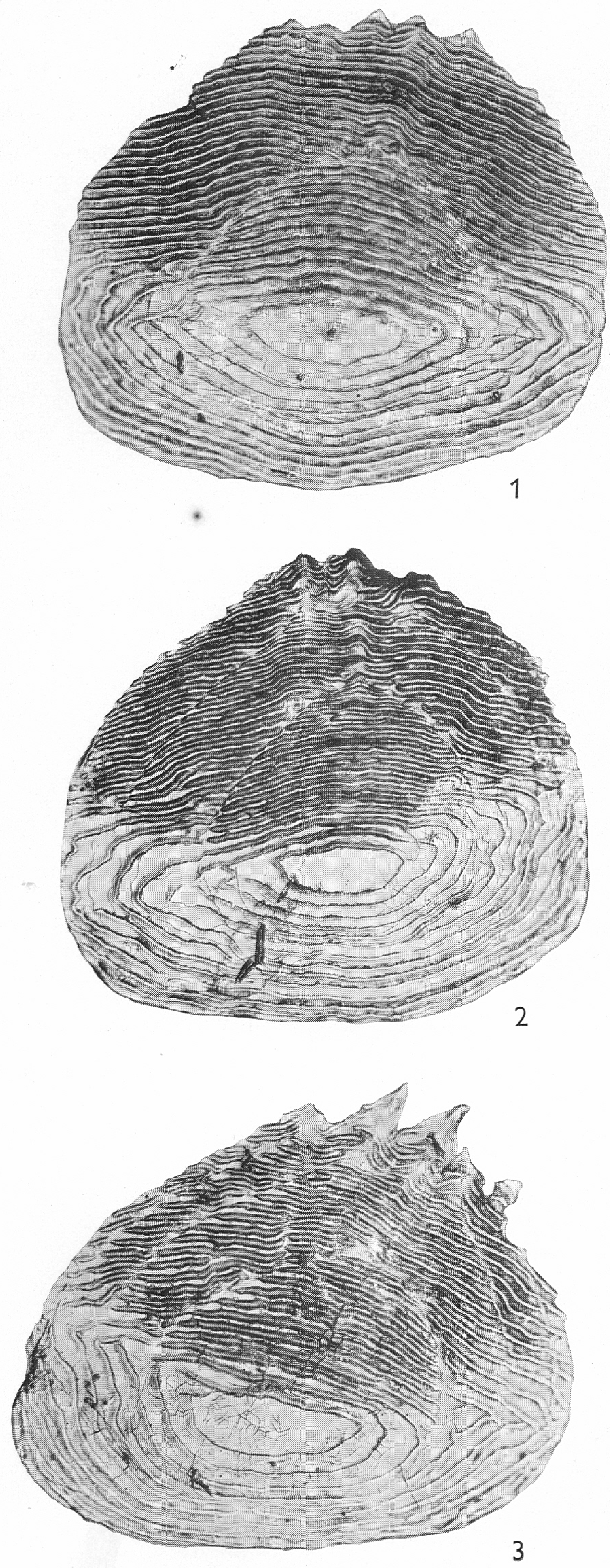

SteVen PLATE I
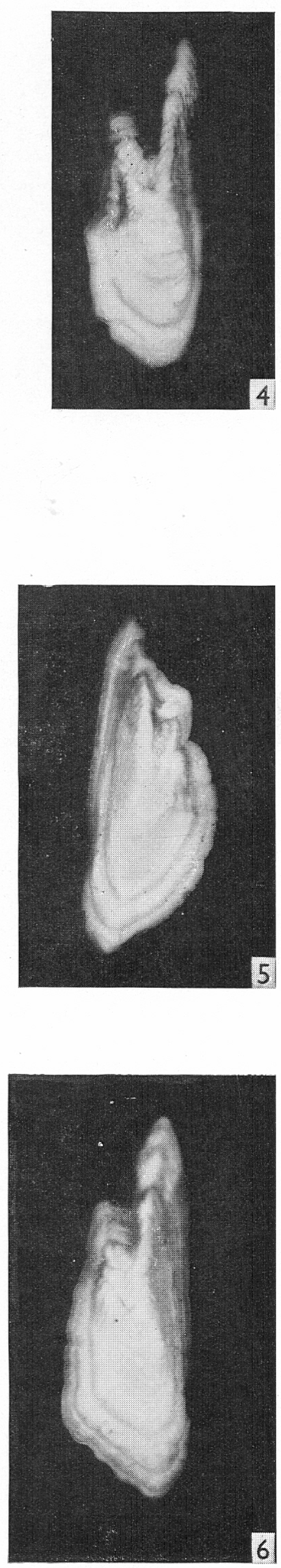